\title{
Dietary supplementation of chromium for finishing pigs
}

\author{
Dante Teixeira Valente Júnior ${ }^{1 *}$ (D) Lívia Maria dos Reis Barbosa ${ }^{2}$ (D) Marcos Henrique Soares $^{1}$ (D) \\ Gustavo de Amorim Rodrigues ${ }^{3}$ (i) Maykelly da Silva Gomes $^{3}$ (i) Caroline Brito da Silva ${ }^{4}$ (1) \\ Lucas Medina Teixeira ${ }^{4}$ (i) Ronaldo Lopes Cunha Júnior ${ }^{4}$ (D) Fernanda Fialho Abranches ${ }^{4}$ (D) \\ Alysson Saraiva ${ }^{5}$ (D)
}

${ }^{1}$ Programa de Pós-graduação em Zootecnia, Universidade Federal de Viçosa (UFV), Viçosa, MG, Brasil.

${ }^{2}$ Faculdade de Medicina Veterinária, Centro Universitário do Espírito Santo (UNESC), Colatina, ES, Brasil.

${ }^{3}$ Programa de Pós-graduação em Zootecnia, Universidade Federal de Viçosa (UFV), Viçosa, MG, Brasil.

${ }^{4}$ Curso de Zootecnia, Universidade Federal de Viçosa (UFV), Viçosa, MG, Brasil.

${ }_{5}^{5}$ Departamento de Zootecnia, Universidade Federal de Viçosa (UFV), Viçosa, MG, Brasil. E-mail: dantetvj97@gmail.com. .Corresponding author.

ABSTRACT: Increasing fat deposition and feed conversion ratio over the days in finishing phase directly influence pork quality and productive profitability. Nonetheless, the slaughter of heavier pigs can result in benefits for the slaughterhouse due to dilution of production and processing costs, as well as economic benefits for the pig producer resulting from the dilution of production costs. Therefore, dietary supplementation of chromium for finishing pigs of high lean-genotypes is a strategy to increase lean tissue accretion and minimize fat deposition, reflecting positively on growth performance. This review discussed recent studies results and mechanisms of action of this modifier of performance and carcass a traits in finishing pigs. Chromium increases the insulin action, facilitating insulin binding to the receptors on cell membrane. As a result, insulin-sensitive cells uptake more glucose, which will be later converted into energy. This additional energy is use to increase protein synthesis, thereby increasing the amount of lean tissue and reducing fat content in the carcass, without altering protein intake by pigs. Chromium also reduces lipid oxidation rate maintaining meat quality for longer period. In conclusion, dietary Cr supplementation for finishing pigs have shown that $0.2 \mathrm{mg} / \mathrm{kg}$ of organic Cr sources for pigs from $\sim 60 \mathrm{~kg}$ until the slaughter can improve growth performance, lean gain and reduce fat content in carcass. However, the development of nanotechnology has allowed the use of inorganic Cr source at $0.2 \mathrm{mg} / \mathrm{kg}$ of inclusion, leading to improve the growth performance and carcass traits of finishing pigs.

Key words: carcass traits, growth performance, mineral, nutrition, swine.

\section{Suplementação de cromo na dieta de suínos em terminação}

RESUMO: O aumento na deposição de gordura e da conversão alimentar durante a fase de terminação são fatores que implicam diretamente na qualidade da carne e também na rentabilidade da cadeia produtiva. Apesar disso, o abate tardio dos suínos pode resultar em beneficios para o frigorifico, pela redução dos custos operacionais por suíno abatido e melhor utilização dos equipamentos, bem como vantagens econômicas para o produtor resultantes da diluição dos custos de produção. Portanto, a suplementação de cromo na ração de suínos de linhagens com maior potencial para deposição de músculo, é uma estratégia para aumentar a deposição de tecido magro e minimizar a deposição de gordura, refletindo positivamente no desempenho. Em vista disso, objetivou-se com este trabalho, apresentar e discutir os mecanismos de ação, finalidades e resultados recentes de estudos na literatura sobre a suplementação desse modificador de carcaça na ração de suínos em terminação. O principal papel do cromo é potencializar a ação da insulina, facilitando a ligação entre a insulina e os seus receptores na membrana celular. Com isso, as células sensiveis à insulina captam maior quantidade de glicose, que posteriormente serão convertidas em energia. Essa energia adicional pode ser utilizada para aumentar a sintese proteica, aumentando assim, a quantidade de carne magra e reduzindo o teor de gordura na carcaça, sem alterar o consumo de proteína pelos animais. O cromo também diminui a taxa de oxidação lipídica, mantendo a qualidade da carne por mais tempo. Em conclusão, a suplementação dietética de Cr para suínos em terminação mostra que 0,2 mg/kg de fontes orgânicas de Cr para suínos de $\sim 60 \mathrm{~kg}$ até o abate podem melhorar o desempenho, ganho de massa magra e reduzir o teor de gordura na carcaça. No entanto, o desenvolvimento da nanotecnologia tem permitido o uso de fonte inorgânica de Cr na dose de $0,2 \mathrm{mg} / \mathrm{kg}$ de inclusão, melhorando o desempenho e as características de carcaça de suínos em terminação.

Palavras-chave: características da carcaça, desempenho, minerais, nutrição, suínos.

\section{INTRODUCTION}

Pork is the most consumed meat in the world, reaching a total of 112,433 thousand tons in 2018 (USDA, 2018), highlighting the great importance of pig industry in the world meat market, providing consumers with food of high biological value.

Over the years, with advances in breeding programs, genetic strains with less backfat thickness 
and greater potential for muscle deposition have been selected (WOOD \& WHITTEMORE, 2006).

In the finishing phase is where the greatest change in the carcass composition occurs. The increase of subcutaneous fat deposition and feed conversion ratio over the days directly affect carcass quality and pig production profitability (VALENTE JÚNIOR et al., 2019).

Heavier pigs result in benefits for the abattoir due to dilution mainly of operational costs per slaughtered pig and better use of equipment, as well as economic advantages resulted from higher carcass yield and commercial cuts (WOOD \& WHITTEMORE, 2006).

Conversely, as pigs become heavier, feed efficiency is reduced due to increase in fat deposition, which cause a decrease in growth performance and an increase in production costs, in addition to the risk of not meeting the carcass quality requirements imposed by the abattoir (MARCOLLA et al., 2017). Thus, one of the main challenges of pig industry is to slaughter pigs over $100 \mathrm{~kg}$ with higher lean gain and less fat deposition (MADEIRA et al., 2016).

Therefore, dietary supplementation of carcass modifying additives for finishing pigs of high lean-genotypes can contribute to increase lean gain and reduce fat deposition (MARCOLLA et al., 2017). Thus, it would be possible to slaughter heavier pigs without compromising carcass quality (APPLE et al., 2004), together with improving growth performance and lowering production cost.

The mineral chromium $(\mathrm{Cr})$ has been used in pig diets in order to may improve carcass traits and growth performance.

In view of this, the aim of this review is to present and discuss the mechanisms of action, purposes of use and recent results of studies on dietary supplementation of chromium for finishing pigs.

\section{Chromium}

Cr can act on metabolism in several ways, as it is associated with actions of various enzymes and hormones. This mineral is present in food mainly in trivalent form $\left(\mathrm{Cr}^{+3}\right)$, as it is the form that gives greater chemical stability during oxidation (GARCÍA \& GARNS, 2004), which occurs on metabolism of carbohydrates, proteins and lipids (MERTZ, 1993).

The first source used for $\mathrm{Cr}$ supplementation was $\mathrm{Cr}$ picolinate (CrPic). However, currently several other sources of $\mathrm{Cr}$ are used in pig diets, such as $\mathrm{Cr}$ chloride complexes $(\mathrm{CrCl}), \mathrm{Cr}$ methionine chelates (CrMet), Cr nanocomposite (CrNan), Cr nicotinate (CrNic), $\mathrm{Cr}$ propionate (CrProp) and $\mathrm{Cr}$ yeast
(CrYeast) (WANG et al., 2007). It is known that chelates of $\mathrm{Cr}$ are more absorbed and used by pigs compared to non-chelated sources (NATIONAL RESEARCH COUNCIL, 1997).

Cr's main role is to potentialize the action of insulin, facilitating the bind between insulin and insulin receptors on cell membrane (NATIONAL RESEARCH COUNCIL, 1997). As a result, insulin-sensitive cells capture greater amount of glucose, which will be later converted into energy (CLARKSON, 1997).

This additional energy is used to improve the use of nutrients by increasing lean gain and reducing fat content in the carcass, without altering the protein intake (WANG et al., 2007; JACKSON et al., 2009; SALES \& JANCIK, 2011). Consequently, this contributes to reduce the environmental impact caused by nitrogen excretion into environment (LINDEMANN, 1999).

It has known that muscle deposition is more efficient compared to adipose tissue deposition, since less dietary energy is required to deposit muscle tissue in comparison with adipose tissue; thereby, dietary $\mathrm{Cr}$ supplementation for finishing pigs can improve feed efficiency and reduce feed costs (LINDEMANN \& LU, 2019).

In this way, dietary supplementation of chromium for finishing pigs of high lean-genotypes is a strategy to increase lean tissue accretion and minimize fat deposition, reflecting positively on growth performance, reported in some studies (Table 1).

Evaluating $\mathrm{Cr}$ and its different sources $(\mathrm{Cr}$ propionate, $\mathrm{Cr}$ picolinate, $\mathrm{Cr}$ yeast and $\mathrm{Cr}$ methionine) on growth performance of castrated and female finishing pigs, LINDEMANN et al. (2008) reported that dietary $\mathrm{Cr}$ yeast $(0.5 \mathrm{mg} / \mathrm{kg})$ improved average daily gain (ADG) compared to the control diet .

LI et al. (2013) evaluated the effects of supplementing diets for finishing barrows (75 to $100 \mathrm{~kg})$ with CrMet $(0,0.3,0.6$, and $0.9 \mathrm{mg} / \mathrm{kg})$ and observed a linear increase in ADG, average daily feed intake (ADFI) and feed conversion ratio (FCR). There was also a linear increase in loin muscle area (LMA) and a decrease in backfat thickness (BF) of pigs fed CrMet diet.

In a study with different sources of dietary fat, JACKSON et al. (2009) reported the inclusion of $0.2 \mathrm{mg} / \mathrm{kg} \mathrm{Cr}$ propionate to finishing gilts did not improve growth performance. However, dietary supplementation of $\mathrm{Cr}$ propionate decreased $\mathrm{BF}$ in $10^{\text {th }}$ rib and increased the percentage of muscle in carcass.

ZHANG et al. (2011) evaluated the effects of $0,0.2$ and $0.4 \mathrm{mg} / \mathrm{kg} \mathrm{Cr}$ picolinate (CrPic) in the 
Table 1 - Studies assessing the effects of different sources and levels of chromium in the diets for growing and finishing pigs on growth performance and carcass traits.

\begin{tabular}{|c|c|c|c|c|c|}
\hline Source & $\begin{array}{l}\text { Level } \\
\mathrm{mg} / \mathrm{kg}\end{array}$ & Animals & Weight & Main results & Reference \\
\hline $\begin{array}{l}\mathrm{Cr} \\
\text { Nanocomposite }\end{array}$ & 0.2 & $\begin{array}{l}\text { Finishing } \\
\text { barrows }\end{array}$ & $\begin{array}{l}65 \text { to } 90 \\
\mathrm{~kg}\end{array}$ & $\begin{array}{l}\text { Reduced FCR. Decreased BF in 10th rib } \\
\text { and increased LMA. }\end{array}$ & WANG et al. (2007) \\
\hline Cr Yeast & 0.5 & Crossbred pigs & $\begin{array}{l}48 \text { to } 114 \\
\mathrm{~kg}\end{array}$ & Improved ADG and FCR. & $\begin{array}{l}\text { LINDEMANN et al. } \\
\text { (2008) }\end{array}$ \\
\hline $\mathrm{Cr}$ Propionate & 0.2 & Finishing gilts & $\begin{array}{l}29 \text { to } 109 \\
\mathrm{~kg}\end{array}$ & $\begin{array}{l}\text { Decreased } \mathrm{BF} \text { in } 10^{\text {th }} \text { rib and increased } \\
\text { the percentage of muscle in carcass. }\end{array}$ & $\begin{array}{l}\text { JACKSON et al. } \\
\qquad(2009)\end{array}$ \\
\hline Cr Picolinate & $\begin{array}{l}0,0.2 \text { and } \\
0.4\end{array}$ & $\begin{array}{l}\text { Growing- } \\
\text { finishing pigs }\end{array}$ & $\begin{array}{l}35 \text { to } 100 \\
\mathrm{~kg}\end{array}$ & $\begin{array}{l}\text { Higher ADG and lower FCR. Increase } \\
\text { in muscle:fat ratio and LMA. }\end{array}$ & ZHANG et al. (2011) \\
\hline Cr Methionine & $\begin{array}{l}0,0.3,0.6 \\
\text { and } 0.9\end{array}$ & $\begin{array}{l}\text { Finishing } \\
\text { barrows }\end{array}$ & $\begin{array}{l}75 \text { to } 100 \\
\mathrm{~kg}\end{array}$ & $\begin{array}{l}\text { Linear increase in ADG, ADFI, FCR } \\
\text { and LMA. Decrease in BF. }\end{array}$ & LI et al. (2013) \\
\hline Cr Methionine & 0.2 & Barrows & $\begin{array}{l}60 \text { to } 107 \\
\mathrm{~kg}\end{array}$ & $\begin{array}{c}\text { Reduced } 72 \mathrm{~h} \text { post-mortem meat lipid } \\
\text { oxidation. Better results of ADG and } \\
\text { FCR. }\end{array}$ & PERES et al. (2014) \\
\hline Cr Nanoparticles & $\begin{array}{l}0,0.1,0.2 \\
\quad \text { and } 0.4\end{array}$ & Finishing pigs & $\begin{array}{l}66 \text { to } 93 \\
\mathrm{~kg}\end{array}$ & $\begin{array}{c}\text { Linear increase in feed efficiency and a } \\
\text { linear reduction in carcass fat } \\
\text { percentage and BF. }\end{array}$ & WANG et al. (2014) \\
\hline Cr Picolinate & 0.4 & Finishing gilts & $\begin{array}{l}52 \text { to } 91 \\
\mathrm{~kg}\end{array}$ & $\begin{array}{l}\text { Increase in carcass weight and loin } \\
\text { muscle depth, and a reduction in BF. }\end{array}$ & HUNG et al. (2015) \\
\hline Cr Nanoparticles & 0.2 & $\begin{array}{l}\text { Growing- } \\
\text { finishing pigs }\end{array}$ & $\begin{array}{l}31 \text { to } 120 \\
\mathrm{~kg}\end{array}$ & $\begin{array}{l}\text { Increase in } \mathrm{ADG} \text { and } \mathrm{ADFI} \text {. Reduction } \\
\text { in } \mathrm{BF} .\end{array}$ & LI et al. (2017) \\
\hline Cr Methionine & 0.2 & $\begin{array}{l}\text { Growing- } \\
\text { finishing pigs }\end{array}$ & $\begin{array}{l}32 \text { to } 110 \\
\mathrm{~kg}\end{array}$ & Reduced FCR and increased LMA. & XU et al. (2017) \\
\hline
\end{tabular}

$\mathrm{ADG}=$ average daily gain; $\mathrm{ADFI}=$ average daily feed intake; $\mathrm{FCR}=$ feed conversion ratio; $\mathrm{LMA}=$ loin muscle area and $\mathrm{BF}=$ backfat thickness.

diets for growing and finishing pigs (35 to $100 \mathrm{~kg}$ ). During growth phase, no differences were observed on growth performance. However, during the finishing phase, pigs fed $1.61 \mathrm{mg} / \mathrm{kg} \mathrm{CrPic} \mathrm{had} \mathrm{better}$ ADG. During the entire period, pigs fed with $\mathrm{CrPic}$ in the diet had higher ADG (6.08\%) and lower FCR $(3.30 \%)$. Regarding carcass quality, an increase in muscle:fat ratio and LMA were observed in pigs fed with $1.61 \mathrm{mg} / \mathrm{kg} \mathrm{CrPic}$.

Similarly, SILVA et al. (2019) observed an increase in ADG and ADFI, and an improvement in FCR with a dietary supplement composed by L-carnitine $(50 \mathrm{mg} / \mathrm{kg}), \mathrm{Cr}$ propionate $(0.2 \mathrm{mg} / \mathrm{kg})$ and organic selenium $(0.3 \mathrm{mg} / \mathrm{kg}) \mathrm{kg})$ for finishing pigs.

LI et al. (2017) also observed an increase in ADG and ADFI of growing and finishing pigs supplemented with $0.2 \mathrm{mg} / \mathrm{kg} \mathrm{Cr}$ nanoparticle in the diet. In addition, the pigs that received $\mathrm{Cr}$ in the diet had a reduction in $\mathrm{BF}$

CARAMORI JÚNIOR et al. (2017) reported that dietary supplementation of Cr-yeast $(0.8$ $\mathrm{mg} / \mathrm{kg})$ and Se-yeast $(0.6 \mathrm{mg} / \mathrm{kg})$ to barrows from 70 to $130 \mathrm{~kg}$ increased Longissimus dorsi depth without affecting pigs' final body weight. In addition, HUNG et al. (2015) observed that $0.4 \mathrm{mg} / \mathrm{kg} \mathrm{Cr}$ picolinate in the diet for finishing gilts promoted an increase in carcass weight and loin muscle depth, and a reduction in BF. The studies above evidenced the effects of $\mathrm{Cr}$ in reducing fat and increasing protein deposition, which improves the growth performance of finishing pigs.

$\mathrm{Cr}$ can also improve meat quality, through decreasing lipid oxidation rate and; consequently, increasing shelf life. AGEs (Advanced Glycation End-products) are complexes formed during glycation between protein and sugar molecules that occurs mainly in high levels of blood glucose. These complexes form free radicals, thus triggering oxidative stress that increases meat lipid oxidation (BIERHAUS et al., 1998; JAKUS \& RIETBROCK, 2004). Cr contributes to decrease the generation of free radicals (PREUSS et al., 1997), increasing glucose uptake by cells and decreasing blood sugar levels (EVANS \& BOWMAN, 1992), which reduces the susceptibility to meat lipid oxidation.

In this sense, TIAN et al. $(2014 ; 2015)$ and XU et al. (2017) observed an improvement in 
antioxidant status of growing and finishing pigs supplemented with $\mathrm{Cr}$ methionine up to $0.4 \mathrm{mg} / \mathrm{kg}$ in the diet. However, higher inclusion of $\mathrm{Cr}$ methionine $(0.8 \mathrm{mg} / \mathrm{kg})$ decreased the serum antioxidant capacity (TIAN et al., 2014; 2015).

PERES et al. (2014) observed that dietary supplementation of $0.2 \mathrm{mg} / \mathrm{kg}$ CrMet for barrows $(60$ to $107 \mathrm{~kg}$ ) reduced the $72 \mathrm{~h}$ post-mortem meat lipid oxidation, suggesting the inclusion of CrMet in in diets for finishing pigs maintain the meat quality for longer period. In addition, CrMet supplementation provided better results of ADG and FCR compared to control diet.

However, there is a need for further investigation to better understand the mechanisms of $\mathrm{Cr}$ and its different sources and levels in reducing meat lipid oxidation.

\section{Chromium on activation of glucose tolerance factor (gtf) and chromodulin}

Higher protein deposition and lower fat deposition in the carcass in response to dietary $\mathrm{Cr}$ supplementation may be related to carbohydrate metabolism, acting as part of the mechanism of insulin signaling amplification, improving glucose and amino acids uptake by muscle tissue cells (EVANS \& BOWMAN, 1992; VINCENT et al., 2000). In this sense, Chromium may increase the cells glucose uptake by activating the glucose tolerance factor (GTF) and chromodulin.

$\mathrm{Cr}$ is a biological active compound of an essential trace that participates in the formation of the molecule GTF. GTF is a low molecular weight organic complex, composed of $\mathrm{Cr}$, nicotinic acid, glycine, cysteine, glutamic acid and calcium, which increases cell membrane fluidity and enhances insulin action, facilitating the binding of insulin with its receptor and increasing the cell's sensitivity to glucose (MIRSKY et al., 1981; MERTZ, 1993).

In this way, in vitro studies indicated that GTF can increase glucose transport in yeast cells (MIRSKY et al., 1981; MIRSKY \& BERDICEVSKY, 1994), adipocytes (TOKUDA et al., 1987), and cardiomyocytes (FISCHER et al., 1992).

In addition, MIRSKY et al. (2016) observed that diabetic rats treated with GTF had lower blood glucose levels than the diabetic ones not treated with GTF $(252 \mathrm{~mL} / \mathrm{dL}$ vs $450 \mathrm{~mL} / \mathrm{dL}$, respectively), suggesting a positive influence of GTF in hyperglycemia control.

GTF regulates blood glucose levels, potentiating insulin activity. When insulin binds to its receptor on the cell membrane, blood glucose levels are reduced due to glucose uptake by cells. Then, glucose is used as an energy source for protein synthesis, regulated by growth hormone $(\mathrm{GH})$ and insulin-like growth factor (IGF-1) (LINDER, 1991). GTF also increases the conversion of thyroxine (T4) to triiodothyronine (T3), hormones that accelerate metabolic rate and increase protein synthesis capacity by muscle cells (BURTON, 1995). Therefore, $\mathrm{Cr}$ is of a great importance since without it GTF molecule is inactive (HOSSAIN et al., 1998).

$\mathrm{Cr}$ is an active compound of another molecule called chromodulin, which is considered a biologically active form of $\mathrm{Cr}$ (ALMEIDA et al., 2010). Therefore, activation of chromodulin could be another pathway of $\mathrm{Cr}$ action on carbohydrate metabolism.

Chromodulin is an oligopeptide composed of $\mathrm{Cr}^{+3}$ and amino acid residues of glycine, cysteine, glutamate and aspartate (YAMAMOTO et al., 1987), which has the function of potentiating insulin signaling (VINCENT, 2001).

Adapted chromodulin activation model is shown in figure 1. Chromodulin is stored as protein in insulin sensitive cells. $\mathrm{Cr}$ is transported in bloodstream mainly by transferrin and when there is an increase in circulating insulin there will be a greater mobilization of chromodulin to tissue cells, and greater mobilization of transferrin receptors from intracellular vesicles to cells membrane. Posteriorly, trasferrin saturated with $\mathrm{Cr}$ molecules binds to its specific receptors and the complex formed is internalized by endocytosis. The acidic $\mathrm{pH}$ in intravesicular space causes digestion of this complex, releasing $\mathrm{Cr}$ to cytosol. Apochromodulin binds to four ions of $\mathrm{Cr}^{+3}$ becoming active as chromodulin form, which in turn binds to cells insulin receptor amplifying the insulin signal (VINCENT, 1994).

As blood glucose levels rise insulin is released quickly into bloodstream. The binding of insulin to its membrane receptors causes a change in the conformation of these receptors that autophosphorylates tyrosine residues transforming the receptor into an active kinase (SALTIEL, 1994).

These changes in insulin receptors promote translocation of glucose transporter type 4 (GLUT 4) to plasma membrane, potentiating the activity of tyrosine kinase, thus increasing membrane sensitivity and improving glucose uptake (VINCENT, 1994; SALTIEL \& KAHN, 2001).

In this sense, TIAN et al. (2014) observed a decrease in glucose and insulin serum levels in pigs supplemented with different levels of CrMet $(0.1$, $0.2,0.4$ or $0.8 \mathrm{mg} / \mathrm{kg}$ ), indicating greater uptake of glucose by cells. 


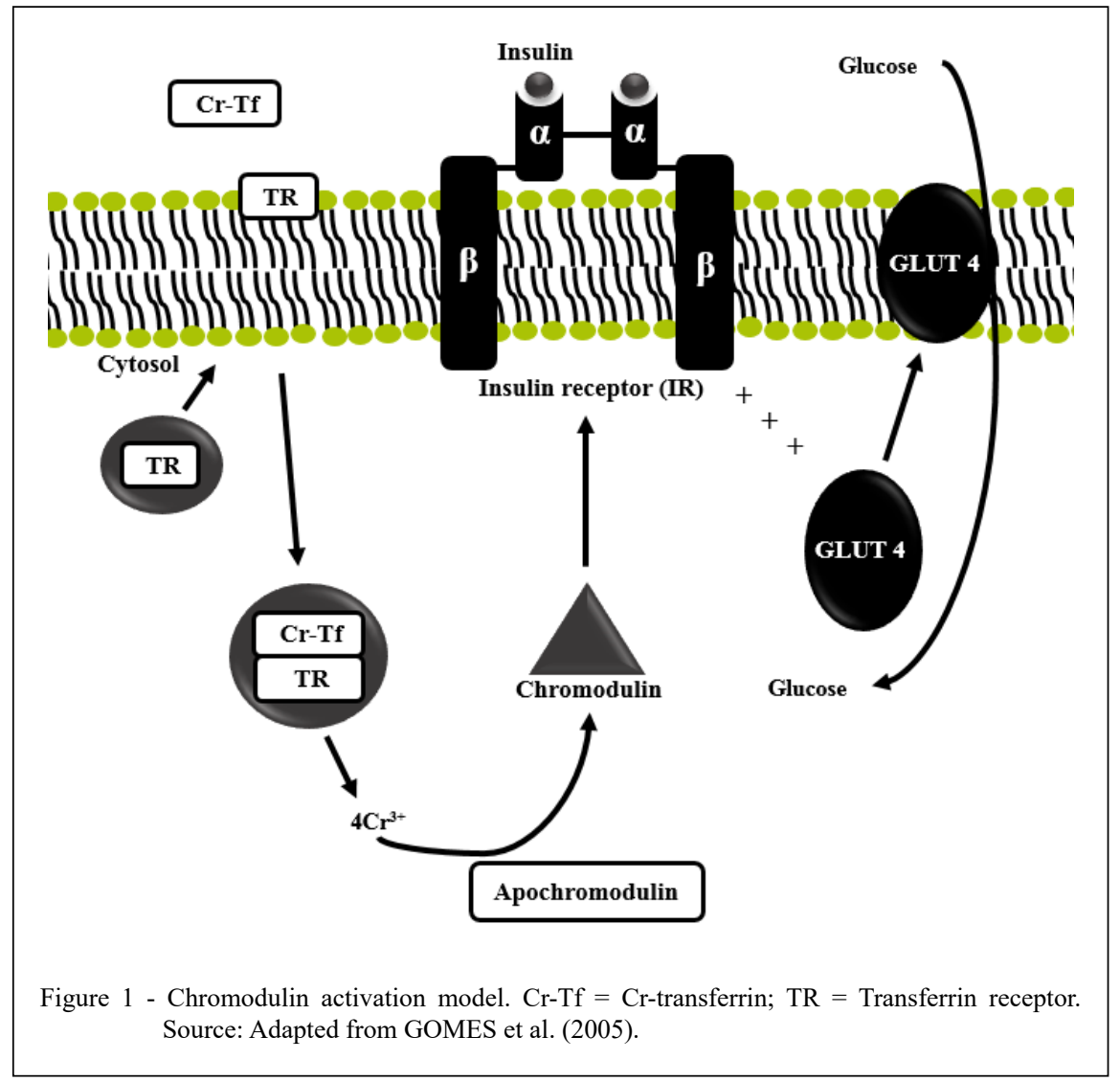

In a study with dietary supplementation of nanocomposite chromium $(0.2 \mathrm{mg} / \mathrm{kg})$ for finishing barrows (65 to $90 \mathrm{~kg}$ ), WANG et al. (2007) reported an increase of IGF-1 and total protein concentrations in serum, and a reduction in glucose and insulin levels. Indicating the mechanism that $\mathrm{Cr}$ exerts on protein synthesis, resulting in increased LMA and reduced body and $\mathrm{BF}$ in that study. In addition, the authors also observed a reduction in FCR $(3.30 \%)$ in pigs fed with the diet supplemented with $\mathrm{Cr}$.

Similar results were reported by WANG et al. (2014), who evaluated the supplementation of $\mathrm{Cr}$ nanoparticles $(0,0.1,0.2$, and $0.4 \mathrm{mg} / \mathrm{kg}$ ) for finishing pigs. The authors reported a linear increase in feed efficiency and a linear reduction in carcass fat percentage and BF. In addition, pigs fed $\mathrm{Cr}$ in the diet had an increase in serum IGF-1 concentrations and a reduction in plasma insulin.

\section{Chromium on protection of the cortical actin filament} (f-actin)

The structural dynamics of the actin filament (F-actin) is a fundamental characteristic of glucose transport in skeletal muscle cells (BROZINICK JR et al., 2004; MCCARTHY et al., 2006). F-actin is also essential for GLUT4, which plays an important role in glucose uptake by skeletal muscle cells as well as in regulation of blood glucose levels (TSAO et al., 2000). Therefore, compromising the structure of F-actin can decrease glucose uptake by cells, causing metabolic disorders.

HABEGGER et al. (2012) observed in muscle tissues of humans and animals resistant to insulin, a reduction of $\mathrm{F}$-actin due to increase in cholesterol in the skeletal muscle membrane, suggesting the increase in cholesterol deposition in the membrane may compromise the F-actin structure. According to CHEN et al. (2006), $\mathrm{Cr}^{+3}$ can increase GLUT4 activity and glucose transport in 3T3-L1 adipocytes by reducing cholesterol in the cell membrane.

The mechanisms involved in reduction of cholesterol in the cell membrane by $\mathrm{Cr}$ are not clear. In vitro and in vivo studies have reported that $\mathrm{Cr}^{+3}$ increases the activity of 5' adenosine monophosphateactivated protein kinase (AMPK) (WANG et al., 2009; 
HOFFMAN et al., 2014). This leads to an increase of fatty acids $\beta$-oxidation and to a decrease of muscle tissue lipogenesis, indicating the effects of chromium on protection of F-actin, as well as on carcass traits (MUOIO et al., 1999). For this, phosphorylated AMPK inhibits 3-Hydroxy-3-methylglutarylcoenzyme A (HMG-CoA) reductase, which is one of the main enzymes in endogenous cholesterol synthesis (PEDERSEN, 1994). Thus, the increase in AMPK activity protects the cell membrane against the accumulation of excess cholesterol, reducing the damage on F-actin (HABEGGER et al., 2012).

However, studies evaluating the action of $\mathrm{Cr}$ on serum cholesterol levels have shown inconsistent results, ranging from lack of effect (MATTHEWS et al., 2001; BURGOS et al., 2016), increase (SHELTON et al., 2003) or reduction in serum cholesterol (LIEN et al., 2001; PARK et al., 2009) in pigs supplemented with CrPic in the diet.

Evaluating the effects of dietary supplementation of $0.2 \mathrm{mg} / \mathrm{kg} \mathrm{CrPic}$ for finishing gilts, BURGOS et al. (2016) did not observe differences in serum total cholesterol levels. However, these authors reported that cholesterol concentrations in Longissimus thoracis muscle and in adipose tissue were considerably lower in pig supplemented with CrPic compared to those not supplemented.

\section{Chromium on regulation of gene expression}

In addition to enzymes/proteins already discussed in this review that act positively on glucose uptake by the cells, several other factors are involved in regulation of glucose metabolism. The increase in expression of some genes, such as glycogen synthase (GS) and uncoupling protein-3 (UCP3), may play an important role in physiological function of $\mathrm{Cr}$ (QIAO et al., 2009).

GS regulates glycogen synthesis and also plays a role in glucose storage (HUPPERTZ et al., 2001). However, its activation is regulated by insulin, which promotes dephosphorylation and activation of GS by inactivation of glycogen synthase kinase 3 (GSK3) through phosphorylation by Akt (BOUSKILA et al., 2008).

The UCP3 stimulates glucose transport and GLUT4 translocation to the surface of skeletal muscle cells, by activating a phosphoinositide 3 kinase-dependent pathway (HUPPERTZ et al., 2001).

QIAO et al. (2009) reported that $\mathrm{Cr}$ positively regulates the mRNA expression of insulin receptor, GLUT4, GS and UCP3 in skeletal muscle cells, which potentialize the uptake and metabolism of insulin-stimulated glucose.
Hormone sensitive lipase (HSL) is considered as a key enzyme in fatty acid mobilization, mainly hydrolyzing triacylglycerol, diacylglycerol, and monoacylglycerol into free fatty acid (LAFONTAN \& LANGIN, 2009). Fatty acid synthetase (FAS) plays a key role in de novo lipogenesis of long-chain fatty acids (LIU et al., 2010). Therefore, higher and lesser activity of HSL and FAS; respectively, in the adipose tissue may reduce the carcass fat content. In this sense, dietary $\mathrm{Cr}$ supplementation may improve the carcass lean: fat ratio by upregulate HSL and downregulate FAS activity.

In this way, evaluating the effects of dietary $\mathrm{Cr}$ nanoparticles supplementation $(0,0.1$, 0.2 , and $0.4 \mathrm{mg} / \mathrm{kg}$ ) for barrows on lipid metabolism, WANG et al. (2014) observed a reduction in the enzyme FAS and an increase in HSL and free fatty acids in adipose tissue, resulting in greater lipid oxidation and less lipogenesis in pigs supplemented with $\mathrm{Cr}$. Therefore, these pigs had less fat and greater muscle deposition in carcass.

\section{CONCLUSION}

The results of dietary $\mathrm{Cr}$ supplementation for finishing pigs have shown that $0.2 \mathrm{mg} / \mathrm{kg}$ of organic $\mathrm{Cr}$ sources, such $\mathrm{Cr}$ Methionine, Cr Picolinate and $\mathrm{Cr}$ Yeast for pigs from $\sim 60 \mathrm{~kg}$ until the slaughter can improve growth performance, lean gain and reduce fat content in carcass. However, the development of nanotechnology has allowed the use of inorganic $\mathrm{Cr}$ source at $0.2 \mathrm{mg} / \mathrm{kg}$ of inclusion, based on the increase in $\mathrm{Cr}$ bioavailability, leading to improve the growth performance and carcass traits of finishing pigs.

\section{ACKNOWLEDGEMENTS}

The authors would like to thank the Coordenação de Aperfeiçoamento de Pessoal de Nível Superior (CAPES) for financial support.

\section{DECLARATION OF CONFLICT OF INTERESTS}

The authors declare that the research was conducted in the absence of any commercial or financial relationships that could be construed as a potential conflict of interest.

\section{AUTHORS' CONTRIBUTIONS}

The authors contributed equally to the manuscript.

\section{REFERENCES}

ALMEIDA, V. V. et al. Ractopamine, chromium-methionine and their combinations as metabolism modifier feed additives of 
growing and finishing pigs. Revista Brasileira de Zootecnia, v.39, n.9, p.1969-1977, 2010. Available from: <http://dx.doi. org/10.1590/S1516-35982010000900015>. Accessed: May, 25, 2020. doi: 10.1590/S1516-35982010000900015.

APPLE, J. K. et al. Effects of dietary lysine and energy density on performance and carcass characteristics of finishing pigs fed ractopamine. Journal of Animal Science, v.82, n.11, p.3277-3287, 2004. Available from: $<$ https://doi.org/10.2527/2004.82113277x>. Accessed: May, 25, 2020. doi: 10.2527/2004.82113277x.

BIERHAUS, A. et al. AGEs and their interaction with AGEreceptors in vascular disease and diabetes mellitus. I. The AGE concept. Cardiovascular Research, v.37, n.3, p.586600 , 1998. Available from: <https://doi.org/10.1016/S0008 6363(97)00233-2>. Accessed: May, 25, 2020. doi: 10.1016/ S0008-6363(97)00233-2.

BOUSKILA, M. et al. Insulin promotes glycogen synthesis in the absence of GSK3 phosphorylation in skeletal muscle. American Journal of Physiology-Endocrinology and Metabolism, v.294, n.1, p.E28-E35, 2008. Available from: <https://doi.org/10.1152/ ajpendo.00481.2007>. Accessed: May, 25, 2020. doi: 10.1152/ ajpendo.00481.2007.

BROZINICK JR, J. T. et al. Disruption of cortical actin in skeletal muscle demonstrates an essential role of the cytoskeleton in glucose transporter 4 translocation in insulin-sensitive tissues. Journal of Biological Chemistry, v.279, n.39, p.40699-706, 2004. Available from: < https://doi.org/10.1074/jbc.M402697200>. Accessed: May, 25, 2020. doi: 10.1074/jbc.M402697200.

BURGOS, C. et al. The effects of chromium picolinate and simvastatin on pig serum cholesterol contents in swine muscular and adipose tissues. Livestock Science, v.185, p.74-78, 2016. Available from: <https://doi.org/10.1016/j.livsci.2016.01.014>. Accessed: May, 25, 2020. doi: 10.1016/j.livsci.2016.01.014.

BURTON, J. L. Supplemental chromium: its benefits to the bovine immune system. Animal Feed Science and Technology, v.53, n.2, p.117-133, 1995. Available from: <https://doi.org/10.1016/03778401(95)02016-S > . Accessed: May, 25, 2020. doi: 10.1016/0377. 8401(95)02016-S.

CARAMORI JÚNIOR, J. G. et al. Chromium and seleniumenriched yeast for castrated finishing pigs: Effects on performance and carcass characteristics. Semina: Ciências Agrárias, v.38, n.6, p.3851-3860, 2017. Available from: <https://doi. org/10.5433/1679-0359.2017v38n6p3851>. Accessed: May, 25, 2020. doi: $10.5433 / 1679-0359.2017 \mathrm{v} 38 \mathrm{n} 6 \mathrm{p} 3851$.

CHEN, G. et al. Chromium activates glucose transporter 4 trafficking and enhances insulin-stimulated glucose transport in 3 T3-L1 adipocytes via a cholesterol-dependent mechanism. Molecular Endocrinology, v.20, n.4, p.857-870, 2006. Available from: <https://doi.org/10.1210/me.2005-0255>. Accessed: May, 25, 2020. doi: 10.1210/me.2005-0255.

CLARKSON, P. M. Effects of exercise on chromium levels: is supplementation required. Sports Medicine, v.23, n.6, p.341349, 1997. Available from: <https://doi.org/10.2165/00007256199723060-00001>. Accessed: May, 25, 2020. doi: 10.2165/00007256-199723060-00001.

EVANS, G. W., BOWMAN, T. D. Chromium picolinate increases membrane fluidity and rate of insulin internalization. Journal of
Inorganic Biochemistry, v.46, n.4, p.243-250, 1992. Available from: <https://doi.org/10.1016/0162-0134(92)80034-S>. Accessed: May, 25, 2020. doi: 10.1016/0162-0134(92)80034-S.

FISCHER, Y. et al. Alanine and hyperosmolarity are responsible for the stimulation of cardiomyocyte glucose transport by samples containing glucose tolerance factor. Life Sciences, v. 50, n. 25 , p.1963-72, 1992. Available from: <https://doi.org/10.1016/00243205(92)90526-u>. Accessed: May, 25, 2020. doi: 10.1016/00243205(92)90526-u

GARCÍA, A. G., GARNS, P. M. Papel del cromo y del cinc em el metabolismo de la insulina. Revista Medica del IMSS, v.42, n.4, p.347-352, 2004. Available from: <https://www.medigraphic.com/ cgi-bin/new/resumen.cgi?IDARTICULO=2011>. Accessed: May, 25,2020 .

GOMES M. R. et al. Considerations about chromium, insulin and physical exercise. Revista Brasileira de Medicina do Esporte, v.11, n.5, p.246e-250e, 2005. Available from: <http://dx.doi. org/10.1590/S1517-86922005000500003>. Accessed: May, 25, 2020. doi: $10.1590 / \mathrm{S} 1517-86922005000500003$.

HABEGGER, K. M. et al. Fat-induced membrane cholesterol accrual provokes cortical filamentous actin destabilization and glucose transport dysfunction in skeletal muscle. Diabetologia, v.55, n.2, p.457-467, 2012. Available from: <https://doi. org/10.1007/s00125-011-2334-y>. Accessed: May, 25, 2020. doi: $10.1007 / \mathrm{s} 00125-011-2334-\mathrm{y}$.

HOFFMAN, N. J. et al. Chromium enhances insulin responsiveness via AMPK. Journal of Nutritional Biochemistry, v.25, n.5, p.565-572, 2014. Available from: <https://doi.org/10.1016/j. jnutbio.2014.01.007>. Accessed: May, 25, 2020. doi: 10.1016/j. jnutbio.2014.01.007.

HOSSAIN, S. M. et al. Growth performance and carcass composition of broiler fed supplemental chromium from chromium yeast. Animal feed science technology, v.71, n.3-4, p.217-228, 1998. Available from: <https://doi.org/10.1016/S03778401(97)00160-0>. Accessed: May, 25, 2020. doi: 10.1016/S03778401(97)00160-0.

HUNG, A. T. et al. Dietary chromium picolinate of varying particle size improves carcass characteristics and insulin sensitivity in finishing pigs fed low- and high-fat diets. Animal Production Science, v.55, p.454-460, 2015. Available from: <http://dx.doi.org/10.1071/ AN12255>. Accessed: May, 25, 2020. doi: 10.1071/AN12255.

HUPPERTZ, C. et al. Uncoupling protein 3 (UCP3) stimulates glucose uptake in muscle cells through a phosphoinositide 3-kinasedependent mechanism. Journal of Biological Chemistry, v.276, p.12520-12529, 2001. Available from: <https://doi.org/10.1074/ jbc.M011708200>. Accessed: May, 25, 2020. doi: 10.1074/jbc. M011708200

JACKSON, A. R. et al. The effect of chromium as chromium propionate on growth performance, carcass traits, meat quality, and the fatty acid profile of fat from pigs fed no supplemented dietary fat, choice white grease, or tallow. Journal of Animal Science, v.87, n.12, p.4032-4041, 2009. Available from: $<$ https:// doi.org/10.2527/jas.2009-2168>. Accessed: May, 25, 2020. doi: $10.2527 /$ jas.2009-2168.

JAKUS, V., RIETBROCK, N. Advanced glycation end products and the progress of diabetic vascular complications. Physiological 
Research, v.53, p.131-142, 2004. Available from: <https://www. biomed.cas.cz/physiolres/2004/issue2/53 131.htm>. Accessed: May, 25, 2020

LAFONTAN, M., LANGIN, D. Lipolysis and lipid mobilization in human adipose tissue. Progress in Lipid Research, v.48, n.5, p.275-297, 2009. Available from: <http://dx.doi.org/10.1016/j. plipres.2009.05.001>. Accessed: Oct. 06, 2020. doi: 10.1016/j. plipres.2009.05.001.

LI, T. Y. et al. Effects of nanoparticle chromium on chromium absorbability, growth performance, blood parameters and carcass traits of pigs. Animal Production Science, v.57, p.1193-1200, 2017. Available from: <http://dx.doi.org/10.1071/AN15142>. Accessed: May, 25, 2020. doi: 10.1071/AN15142.

LI, Y. S. et al. Effects of dietary chromium methionine on growth performance, carcass composition, meat colour and expression of the colour-related gene myoglobin of growing-finishing pigs. AsianAustralasian Journal of Animal Sciences, v.26, n.7, p.1021-1029, 2013. Available from: <https://doi.org/10.5713/ajas.2013.13012>. Accessed: May, 25, 2020. doi: 10.5713/ajas.2013.13012.

LIEN, T. -F. et al. Effect of supplemental levels of chromium picolinate on the growth performance, serum traits, carcass characteristics and lipid metabolism of growing-finishing pigs. Animal Science, v.72, p.289-296, 2001. Available from: <https:// doi.org/10.1017/S1357729800055788>. Accessed: Oct. 07, 2020. doi: $10.1017 / \mathrm{S} 1357729800055788$.

LINDEMANN, M. D. Chromium and swine nutrition. Journal of Trace Elements in Medicine and Biology, v.12, n.2, p.149-161, 1999. Available from: <https://doi.org/10.1002/ (SICI) 1520-670X(1999) 12:2<149::AID-JTRA12>3.0.CO;2-R >. Accessed: May, 25, 2020. doi: 10.1002/(SICI)1520670X(1999)12:2<149::AID-JTRA12>3.0.CO;2-R.

LINDEMANN, M. D. et al. Effect of chromium source on tissue concentration of chromium in pigs. Journal of Animal Science, v.86, n.11, p.2971-2978, 2008. Available from: <https://doi. org/10.2527/jas.2008-0888>. Accessed: May, 25, 2020. doi: $10.2527 /$ jas.2008-0888

LINDEMANN, M. D., LU, N. Chapter 3 - Use of chromium as an animal feed supplement. The Nutritional Biochemistry of Chromium (III), p.79-125, 2019. Available from: <https://doi org/10.1016/B978-0-444-64121-2.00003-9>. Accessed: May, 25, 2020. doi: 10.1016/B978-0-444-64121-2.00003-9.

LINDER, M. C. Nutritional Biochemistry and Metabolism: with Clinical Applications. 2nd ed. New York: Elsevier, 1991. 603p.

LIU, Y. et al. Evaluation of inhibition of fatty acid synthase by ursolic acid: Positive cooperation mechanism. Biochemical and Biophysical Research Communications, v.392, n.3, p.386-390, 2010. Available from: <https://doi.org/10.1016/j. bbrc.2010.01.031>. Accessed: Oct. 06, 2020. doi: 10.1016/j. bbrc.2010.01.031

MADEIRA, M. S. et al. Influence of betaine and arginine supplementation of reduced protein diets on fatty acid composition and gene expression in the muscle and subcutaneous adipose tissue of cross-bred pigs. British Journal of Nutrition, v.115, n.6, p.937-950, 2016. Available from: <https://doi.org/10.1017/ S0007114515005218>. Accessed: May, 25, 2020. doi: 10.1017/ $\mathrm{S} 0007114515005218$
MARCOLLA, C. S. et al. Chromium, CLA, and ractopamine for finishing pigs. Journal of Animal Science, v.95, n. 10, p.4472-4480, 2017. Available from: <https://doi.org/10.2527/jas2017.1753>. Accessed: May, 25, 2020. doi: 10.2527/jas2017.1753.

MATTHEWS, J. O. et al. Effect of chromium picolinate and chromium propionate on glucose and insulin kinetics of growing barrows and on growth and carcass traits of growing-finishing barrows. Journal of Animal Science, v.79, n.8, p.2172-2178, 2001. Available from: <https://doi.org/10.2527/2001.7982172x>. Accessed: May, 25, 2020. doi: 10.2527/2001.7982172x.

MCCARTHY, A. M. et al. Loss of cortical actin filaments in insulinresistant skeletal muscle cells impairs GLUT4 vesicle trafficking and glucose transport. American Journal of Physiology-Cell Physiology, v.291, n.5, p.C860-C868, 2006. Available from: $<$ https://doi.org/10.1152/ajpcell.00107.2006>. Accessed: May, 25, 2020. doi: 10.1152/ajpcell.00107.2006.

MERTZ, W. Chromium in human nutrition: A review. The Journal of Nutrition, v.123, n.4, p.626-633, 1993. Available from: <https:// doi.org/10.1093/jn/123.4.626>. Accessed: May, 25, 2020. doi: 10.1093/jn/123.4.626.

MIRSKY N., BERDICEVSKY, I. Effects of insulin and glucose tolerance factor (GTF) on glucose uptake by yeast cells. Biological Signals, v.3, n.6, p.271-277, 1994. Available from: <https:// doi.org/10.1159/000109554>. Accessed: May, 25, 2020. doi: $10.1159 / 000109554$

MIRSKY, N. et al. Inhibition of diabetic cataract by glucose tolerance factor extracted from yeast. Experimental Biology and Medicine, v.241, n.8, p.817-829, 2016. Available from: <https:// doi.org/10.1177/1535370215627031>. Accessed: May, 25, 2020. doi: $10.1177 / 1535370215627031$.

MIRSKY, N. et al. The effect of glucose tolerance factor in glucose uptake by yeast cells. Journal of Inorganic Biochemistry, v.15, n.3, p.275-279, 1981. Available from: <https://doi.org/10.1016/ s0162-0134(00)80163-4>. Accessed: May, 25, 2020. doi: 10.1016/ s0162-0134(00)80163-4

MUOIO, D. M. et al. AMP-activated kinase reciprocally regulates triacylglycerol synthesis and fatty acid oxidation in liver and muscle: evidence that sn-glycerol-3-phosphate acyltransferase is a novel target. Biochemical Journal, v.338, n.3, p.783-791,1999. Available from: <https://doi.org/10.1042/0264-6021:3380783>. Accessed: May, 25, 2020. doi: 10.1042/0264-6021:3380783.

NATIONAL RESEARCH COUNCIL. The Role of Chromium in Animal Nutrition, Washington, DC: National Academic Press, 1997.

PARK J. et al. Effects of different sources of dietary chromium on growth, blood profiles and carcass traits in growing-finishing pigs. Asian-Australasian Journal of Animal Sciences, v.22, n.11, p.1547-1554, 2009. Available from: <https://doi.org/10.5713/ ajas.2009.80633>. Accessed: Oct. 07, 2020. doi: 10.5713/ ajas.2009.80633.

PEDERSEN, T. R. Randomised trial of cholesterol lowering in 4444 patients with coronary heart disease: the scandinavian simvastatin survival study. The Lancet, v.344, n.8934, p.13831389, 1994. Available from: <https://doi.org/10.1016/S01406736(94)90566-5/>. Accessed: May, 25, 2020. doi: 10.1016/ S0140-6736(94)90566-5/.

Ciência Rural, v.51, n.6, 2021. 
PERES, L. M. et al. Effect of supplementing finishing pigs with different sources of chromium on performance and meat quality. Revista Brasileira de Zootecnia, v.43, n.7, p.369375, 2014. Available from: <http://dx.doi.org/10.1590/S151635982014000700005>. Accessed: May, 25, 2020. doi: 10.1590/ S1516-35982014000700005

PREUSS, H. G. et al. Effects of different chromium compounds on blood pressure and lipid peroxidation in spontaneously hypertensive rats. Clinical Nephrology, v.47, n.5, p.325-330, 1997. Available from: <https://pubmed.ncbi.nlm.nih.gov/9181280/>. Accessed: May, 25, 2020. PMID: 9181280.

QIAO, W. et al. Chromium improves glucose uptake and metabolism through upregulating the mRNA levels of IR, GLUT4, GS, and UCP3 in skeletal muscle cells. Biological Trace Element Research, v.131, n.2, p.133-142, 2009. Available from: <https:// doi.org/10.1007/s12011-009-8357-2>. Accessed: May, 25, 2020. doi: $10.1007 / \mathrm{s} 12011-009-8357-2$

SALES, J., JANCIK, F. Effects of dietary chromium supplementation on performance, carcass characteristics and meat quality of growing- finishing swine: A meta-analysis. Journal of Animal Science, v.89, p.4054-4067, 2011. Available from: $<$ https://doi.org/10.2527/jas.2010-3495>. Accessed: May, 25, 2020. doi: $10.2527 /$ jas.2010-3495.

SALTIEL, A. R. The paradoxical regulation of protein phosphorylation in insulin action. The FASEB Journal, v.8, n.13, p.1034-1040, 1994. Available from: <https://doi.org/10.1096/ fasebj.8.13.7926368>. Accessed: May, 25, 2020. doi: 10.1096/ fasebj.8.13.7926368.

SALTIEL, A. R., KAHN, C. R. Insulin signalling and the regulation of glucose and lipid metabolism. Nature, v.414, p.799-806, 2001. Available from: $<$ https://doi.org/10.1038/414799a $>$. Accessed: May, 25, 2020. doi: 10.1038/414799a.

SHELTON, J. L. et al. Effect of chromium propionate on growth, carcass traits, pork quality, and plasma metabolites in growing-finishing pigs. Journal of Animal Science, v.81, n.10, p.2515-2524, 2003. Available from: <https://doi. org/10.2527/2003.81102515x>. Accessed: May, 25, 2020. doi: $10.2527 / 2003.81102515 x$.

SILVA, C. A. et al. Effect of dietary supplementation with 1-carnitine, chromium, and selenium on the performance of finishing pigs. Semina: Ciências Agrárias, v.40, n.6, p.32893298, 2019. Available from: <https://doi.org/10.5433/16790359.2019v40n6Supl2p3289>. Accessed: May, 25, 2020. doi: 10.5433/1679-0359.2019v40n6Sup12p3289.

TIAN, Y. Y. et al. Effects of chromium methionine supplementation on growth performance, serum metabolites, endocrine parameters, antioxidant status, and immune traits in growing pigs. Biological Trace Element Research, v.162, p.134-141, 2014. Available from: $<$ https://doi.org/10.1007/s12011-014-0147-9>. Accessed: May, 25, 2020. doi: 10.1007/s12011-014-0147-9.

TIAN, Y. Y. et al. Effects of graded levels of chromium methionine on performance, carcass traits, meat quality, fatty acid profiles of fat, tissue chromium concentrations, and antioxidant status in growing-finishing pigs. Biological Trace Element Research, v.168, p.110-121, 2015. Available from: <https://doi.org/10.1007/ s12011-015-0352-1>. Accessed: May, 25, 2020. doi: 10.1007/ s12011-015-0352-1.
TOKUDA, M. et al. Glucose tolerance factor stimulates 3-0 methylglucose transport into isolated rat adipocytes. Biochemical and Biophysical Research Communications, v.144, n.3, p.12371242, 1987. Available from: <https://doi.org/10.1016/0006291X(87)91443-4>. Accessed: May, 25, 2020. doi: 10.1016/0006291X(87)91443-4.

TSAO, T. S. et al. Amelioration of insulin resistance but not hyperinsulinemia in obese mice overexpressing GLUT4 selectively in skeletal muscle. Metabolism, v.49, n.3, p.340346, 2000. Available from: <https://doi.org/10.1016/s00260495(00)90220-8>. Accessed: May, 25, 2020. doi: 10.1016/s00260495(00)90220-8.

USDA. United States Department of Agriculture. Livestock and Poultry: World Markets and Trade, 2018. Available from: $<$ https://usda.library.cornell.edu/concern/publications/73666448x ?locale $=\mathrm{en}>$. Accessed: May, 25, 2020.

VALENTE JÚNIOR, D. T. et al. Dietary supplementation of betaine for finishing pigs: Review. PubVet, v.13, n.3, p.112, 2019. Available from: <https://doi.org/10.31533/pubvet. v13n3a288.1-12>. Accessed: May, 25, 2020. doi: 10.31533/ pubvet.v13n3a288.1-12.

VINCENT, J. B. Relationship between glucose tolerance factor and low-molecular weight chromium-binding substance. Journal of Nutrition, v.124, n.1, p.117-119, 1994. Available from: <https:// doi.org/10.1093/jn/124.1.117>. Accessed: May, 25, 2020. doi: 10.1093/jn/124.1.117.

VINCENT, J. B. The biochemistry of chromium. Journal of Nutrition, v.130, n.4, p.715-718, 2000. Available from: <https:// doi.org/10.1093/jn/130.4.715>. Accessed: May, 25, 2020. doi: $10.1093 / \mathrm{jn} / 130.4 .715$.

VINCENT, J. B. The bioinorganic chemistry of chromium (III). Polyhedron, v.20, n.1-2, p.1-26, 2001. Available from: <https:// doi.org/10.1016/S0277-5387(00)00624-0>. Accessed: May, 25, 2020. doi: 10.1016/S0277-5387(00)00624-0.

WANG, M. Q. et al. Effects of chromium nanocomposite supplementation on blood metabolites, endocrine parameters and immune traits in finishing pigs. Animal Feed Science and Technology, v.139, n.1-2, p.69-80, 2007. Available from: <https:// doi.org/10.1016/j.anifeedsci.2006.12.004>. Accessed: May, 25, 2020. doi: 10.1016/j.anifeedsci.2006.12.004.

WANG, M. Q. et al. Effects of chromium-loaded chitosan nanoparticles on growth, carcass characteristics, pork quality, and lipid metabolism in finishing pigs. Livestock Science, v.161, n.1, p.123-129, 2014. Available from: <https://doi.org/10.1016/j. livsci.2013.12.029>. Accessed: May, 25, 2020. doi: 10.1016/j. livsci.2013.12.029.

WANG, Y. Q. et al. Chromium picolinate inhibits resistin secretion in insulin-resistant 3 T3-L1 adipocytes via activation of amp-activated protein kinase. Clinical and Experimental Pharmacology \& Physiology, v.36, n.8, p.843-849, 2009. Available from: $<$ https://doi.org/10.1111/j.1440-1681.2009.05164. $\mathrm{x}>$. Accessed: May, 25, 2020. doi: 10.1111/j.14401681.2009.05164.x

WOOD, J.; WHITTEMORE, C. Pig meat and carcass quality. In: Whittemore's science and practice of pig production. 3rd. ed. Oxford, UK: Editora Blackwell Publishing, p.4-64, 2006. 
$\mathrm{XU}, \mathrm{X}$. et al. Effects of chromium methionine supplementation with different sources of zinc on growth performance, carcass traits, meat quality, serum metabolites, endocrine parameters, and the antioxidant status in growing-finishing pigs. Biological Trace Element Research, v.179, p.70-78, 2017. Available from: <https:// doi.org/10.1007/s12011-017-0935-0>. Accessed: May, 25, 2020. doi: 10.1007/s12011-017-0935-0.

YAMAMOTO, A. et al. Isolation of a biologically active low-molecular-mass chromium compound from rabbit liver.
European Journal of Biochemistry, v.165, n.3, p.627-631, 1987. Available from: <https://doi.org/10.1111/j.1432-1033.1987. tb11486.x>. Accessed: May, 25, 2020. doi: 10.1111/j.14321033.1987.tb11486.x.

ZHANG, H. et al. Effect of chromium picolinate supplementation on growth performance and meat characteristics of swine. Biological Trace Element Research, v.141, n.1-3, p.159-169, 2011. Available from: $<$ https://doi.org/10.1007/s12011-010-87279>. Accessed: May, 25, 2020. doi: 10.1007/s12011-010-8727-9. 